\title{
Analisis Pengaruh Memutuskan Menabung dengan Brand Image sebagai Variabel Mediasi
}

\author{
Nur Huri Mustofa ${ }^{1}$, Winna Widyowati ${ }^{2}$ \\ ${ }^{1,2}$ Institut Agama Islam Negeri Salatiga, Indonesia \\ ${ }^{1}$ nurhurimustofa@gmail.com
}

Copyright (C) 2021 The Author

This is an open access article

Under the Creative Commons Attribution-ShareAlike 4.0 International License

\begin{abstract}
This research aims to find out how strong "The Influence of CSR, Shariah Governance, and Service Quality on the Decision to Save with Brand Image as an Intervening Variable" at Bank Rakyat Indonesia (BRI) Syariah KCP Ungaran. In this study using quantitative methods. This data collection method is carried out by distributing questionnaires to customers of Bank BRI Syariah KCP Ungaran. Samples were taken as many as 100 respondents, with random sampling technique. The results of the Ttest test show that in this study the variables of CSR, Shariah Governance, and Service Quality have a positive and significant effect on Saving Decisions and also the variables of CSR, Shariah Governance, and Service Quality have a positive and significant effect on Brand Image. And also from the Ftest test, the variables of CSR, Shariah Governance, and Service Quality have a positive and significant effect on Saving Decisions and on Brand Image. From the Path Test using the Sobel Test that the brand image variable is also able to mediate the CSR, Shariah Governance, and Service Quality variables on saving decisions.
\end{abstract}

Keywords: corporate social responsibility, shariah governance, service quality, brand image, saving decisions

ABSTRAK

Tujuan dari penelitian ini mengetahui seberapa kuat "Pengaruh CSR, Shariah Governance, Dan Kualitas Pelayanan Terhadap Keputusan Menabung Dengan Brand Image Sebagai Variabel Intervening" pada Bank Rakyat Indonesia (BRI) Syariah KCP Ungaran. Dalam penelitian ini menggunakan metode kuantitatif. Metode pengumpulan data ini dilakukan melalui penyebaran kuesioner terhadap nasabah Bank BRI Syariah KCP Ungaran. Sampel yang diambil sebanyak 100 responden, dengan teknik random sampling. Hasil dari $\mathrm{Uji}_{\mathrm{T}} \mathrm{T}_{\text {test }}$ menunjukan bahwa dalam penelitian ini variabel CSR, Shariah Governance, dan Kualitas Pelayanan berpengaruh positif dan signifikan terhadap Keputusan Menabung dan juga variabel CSR, Shariah Governance, dan Kualitas Pelayanan berpengaruh positif dan signifikan terhadap Brand Image. Dan juga dari uji

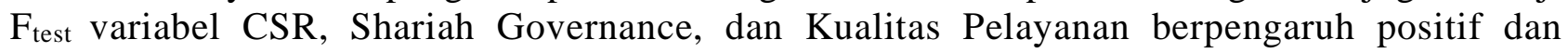
signifikan terhadap Keputusan Menabung dan terhadap Brand Image. Dari Uji Path dengan menggunakan Sobel Test bahwa variabel brand image juga mampu memediasi variabel CSR, Shariah Governance, dan Kualitas Pelayanan terhadap keputusan menabung.

Kata Kunci: corporate social responsibility, shariah governance, kualitas pelayanan, brand image, keputusan menabung 


\section{A. PENDAHULUAN}

Persaingan pebisnis di sekarang ini di Indonesia lebih ketat ditandai dengan banyaknya perbankan di Indonesia yang telah beroperasi. Lebih spesifiknya lagi pada Perbankan Syariah. Bank yang berprinsip syariah sebagai lembaga keuangan dengan melakukan usaha sesuai dengan prinsip dan dasar dalam ekonomi Islam. Kualitas layanan yang diberikan dari karyawan untuk nasabah harus selalu dapat memberi kepuasan, dan nasabah selalu nyaman, sehingga nasabah tersebut merasa dilayani sesuai yang diingkannya, karyawan tersebut wajib memiliki kemampuan yang bisa membuat nasabah tersebut mempercayainya, kepercayaan nasabah terhadap pelayanan yang diberikan karyawan, sehingga nasabah menjadi nyaman. Para karyawan wajib memberi kepedulian terhadap nasabah yang membutuhkan pelayanannya sehingga keinginan dari nasabah dapat selalu diwujudkan (Haris \& T, 2012).

Pada industri perbankan syariah menunjukan perkembangan yang pesat dan berkembang dengan positif, dalam perbankan syariah pertumbuhan aset yang tinggi di tahun 2019 keadaan pasar suatu bank syariah mengalami penurunan dari tahun sebelumnya sampai 3,33\%. Di bulan Juni tahun 2019, bank syariah menyumbang asetnya sebesar 5,95\% dari pangsa pasar industri bank syariah nasional, atau telah mempunyai jumlah aset aset Rp 499,34 triliun. Meskipun saat ini pangsa pasar dalam industri keuangan Islam mencapai 8,29\%, dibanding dengan pangsa industri keuangan tradisional yang lebih kecil.. Ada beberapa faktor yang menyebabkan rendahnya pasar industri keuangan Islam yaitu pemhaman tentang keuangan masyarakat yang rendah, termasuk keuangan Islam (Ruwaidah, 2018).

Menurut OJK perbankan syariah pada Maret 2020 perbanakan syariah selalu menunjukkan perkembangan yang baik dengan Aset, PYD, and DPK yang terus bertumbuh. Market Share pada bank syariah pada Maret sebesar 5,99\%.

\section{Berikut Indikator Utama Perbankan Syariah}

\section{Indikator Utama Perbanakan Syariah}

\begin{tabular}{|c|c|c|c|c|c|}
\hline $\begin{array}{r}\text { Industri } \\
\text { perbankan }\end{array}$ & $\begin{array}{c}\text { Jumlah } \\
\text { Instisusi }\end{array}$ & $\begin{array}{l}\text { Jumlah } \\
\text { Kantor }\end{array}$ & Aset (Triliun) & PYD (Triliun) & $\begin{array}{c}\text { DPK } \\
\text { (Triliun) }\end{array}$ \\
\hline $\begin{array}{c}\text { Bank Umum } \\
\text { Syariah }\end{array}$ & 14 & 1.923 & 349,95 & 228,39 & 289,36 \\
\hline $\begin{array}{c}\text { Unit Usaha } \\
\text { Syariah }\end{array}$ & 20 & 388 & 172,61 & 133,26 & 125,10 \\
\hline $\begin{array}{c}\text { Bank } \\
\text { Pembiayaan } \\
\text { Rakyat } \\
\text { Syariah }\end{array}$ & 163 & 618 & 14,04 & 10,68 & 9,10 \\
\hline TOTAL & 197 & 2.929 & 536,60 & 372,33 & 423,57 \\
\hline
\end{tabular}

Sumber : Snapshot Perbankan Syariah Indonesia 2020 dari (OJK, 2020)

Dalam perbankan syariah agar dapat memberi kepuasan pada nasabah, bank harus menambah kualitas pelayannya dan memperbaiki produknya. Semakin bagus kualitas pelayanan dalam perbankan syariah maka kepuasan para nasabah untuk melakukan keputusan menabung semakin meningkat. Ini mengapa kepuasan nasabah menjadi tolak ukur keberhasilan suatu bank syariah (Ramadani et al., 2018). 


\section{B. KAJIAN LITERATUR}

\section{Keputusan Menabung}

Menurut (Maski, 2010) mengemukakan Keputuan merupakan pemilihan antara beberapa alternatif-alternatif yang meliputi : 1). Beberapa pertimbangan konsumen; 2) Pilihan alternatif yang harus konsumen pilih dan mengambil yang terbaik; 3) Tujuan yang harus dipenuhi, menjadi keputusan konsumen untuk makin mendekatkan pada tujuan terebut. Keputusan yaitu proses terakhir dari tahapan memikirkan masalah digunakan dalam menjawab berbagai pertanyaan dan menjadi apa yang harrus diperbut agr dapat menatasi asalah tersebut, dengan mejatuhkan satu pilihan alternative yang dipilih konsumen. Pengambilan keputusan disini dapat diartikan menjadi suatu proses kelanjutan dari cara pemecahan masalah.

Simpulan dari pengertian diatas bahwa dalam mengambil keputusan dimana konsumen memilik keputusan yang baik secara rasional sesuai dengan data, fakta dan serta informasi dari beberapa alternatif dari berbagai pilihan untuk mencapai tujuan dengan tepat dan efektif dan efisien dan untuk dilaksanakan di masa mendatang.

\section{Brand Image}

Menurut (Inayati \& Wahyuni, 2017) mengemukakan bahwa kesadaran merek merupakan hal yang penting dan harus diketahui konsumen. Suatu kesadaran merek seorang konsumen yang kuat sulit untuk berpindah ke merek lain. Perusahaan dapat menggunakan merek untuk dapat mempromosikan produk agar dikenal luas oleh masyarakat. Keterkaitan suatu merek akan lebih kuat jika bisa dilandasi oleh banyaknya pengalaman. Ingatan konsumen dapat membentuk citra merek dalam benak konsumen. Semakin kuat asosiasi di ingatan konsumen maka semakin kuat pula keyakinan konsumen saat mengambil keputusan saat mengambil keputusan. Suatu merek yang berkualitas, apabila tidak terjadi komunikasi pada saat pemasaran dengan efektif maka akan membuat produk tersebut kalah di pasaran.

Kepercayaan konsumen kepada suatu merek merupakan faktor penting terhadap merek untuk membangun seseorang mengambil keputusan memilih merek tersebut. Brand Image ada dan terbentu dari berbagai informasi dan suatu pengalaman di masa lalu terhadap merek tersebut (Nofriyanti, 2017). Brand Image adalah persepsi atau ingatan dari sekumpulan asosiasi suatu merek yang telah terbentuk dan sudah lekat di benak dan daya ingat seorang konsumen. Seorang konsumen jadikan merek sebagai salah satu pertimbangan penting saat akan membeli suatu produk atau jasa (Said, 2016). Penempatan brand image di diri konsumen wajib secara terus menerus dilakukan agar brand image yang tercipta tetat kuat dan dapat diterima di masyarakat secara positip. Ketika merek sudah terkenal di masyarakat maka akan selalu diingat dan kemungkinan besar konsumen untuk membeli lagi merek tersebut (Musay, 2013).

Kesimpulan dari penjelasan diatas yaitu suatu kesan yang timbul di benak konsumen terhadap suatu merek. Suatu merek menjadi pertimbangan konsumen saat akan membeli suatu produk dan jasa. Maka dari itu, suatu produsen harus terus menerus menempatkan suatu citra positif di benak masyarakat agar selalu diingat dan itu bisa menjadi daya tarik sendiri untuk konsumen membeli lagi suatu merek tersebut. 


\section{Corporate Social Responsibility}

Menurut (Fahham et al., 2015) Tanggungjawab Sosial Perusahaan atau CSR merupakan pertanggung jawaban perusahan yang ditujukan kepada konsumen dan karyawan serta juga pemegang saham dan komunitas dan lingkungan yang wajib dilakukan oleh perusahaan. Tanggungajawab sosial ini sangat berhubungan erat dengan "pembagunan berkelanjutan" yang didasari pada keputusan perusahaan berdasarkan aspek ekonomi, sosial, serta lingkungan.

Menurut (Caesario et al., 2018) citra perusahaan yang baik jika pertanggungjawaban perusahaan kepada masyarakat itu juga baik dan mempunyai daya tarik eksekutif yang handal. Hal ini menunjukan bahwa dalam memenangkan persaingan di dunia bisnis dengan berorientasi dengan citra perusahaan, maka dalam melaksanakan CSR harus secara maksimal dan memperhatikan keluh kesah nasabah untuk mencapai kepuasan nasabah.

Dari penjelasan diatas dapat ditarik kesimpulan yaitu CSR adalah suatu kewajiban perusahaan bisnis yang mengambil dari bagian suatu kegiatan tujuannya melindungi dan selalu mensejahterakan masyarakat.

\section{Shariah Governance}

Umat Islam dalam pembiayaan dilarang menggunakan unsur riba dan sejenisnya. Dalam Islam telah diatur dengan jelas dimana riba merupaka sesuatu hal yang harus dijauhi. Riba menggambarkan sesuatu yang buruk dimata Allah. Allah juga mengancamakan memberi balasan keras kepada seseorang yang memakan riba. Seperti yang disebutkan dalam surah Al-Baqarah ayat 275 yang artinya "Allah menghalalkan jual beli dan mengharamkan riba”.. Ayat ini menjelaskan tentang menolak bahwa pinjaman riba seolaholah menolong mereka yang membutuhkan sebagai perbuatan yang dilarang oleh Allah.

Corporate Governance sebagai system yang memiliki prinsip-prinsip dalam penyusunan dan implementasi strategi perusahaan. Prinsip dasar yang pertama adalah keterbukaanm, karena dengan keterbukaan maka tujuan utama kepercayaan public pada system perusahaan. Yang kedua itu check dan balance dimana adanya pengawasan yang seimbang diantara pihak-pihak yang sedang terlibat dalam perusahaan sehingga dapat menjaga munculnya kekuasaan yang melibatkan kekayaan yang dinikmati tidak sama rata (Endraswati, 2017).

Dari Peraturan Bank Indonesia No.13/2/PBI/2011 yang menjelaskan Pelaksanaan Fungsi Kepatuhan Bank Umum, yang dimaksud dalam hal ini yakni kepatuhan yang mencakup berbahai nilai dan perilaku serta berbagai tindakan untuk mendukung adanya kepatuhan dengan ketentuan Bank Indonesia dan berbagai peraturan perundang-undangan yang berlaku, dan juga terdapat prinsip syariah bagi bank umum syariah dan unit usaha syariah.

\section{Kualitas Pelayanan}

Kualitas pelayanan adalah sesuatu yang menjadi keputusan pelanggan. Artinya kualitas didasarkan pada pengalaman konsumen atau pelanggan saat menggunakan produk atau jasa dengan persyaratan-persyaratan yang berlaku. Kualitas produk dan jasa ini didefinisikan sebagai bentuk gabungan antara karakteristik produk dan jasa yang dihasilkan dari suatu 
pemasaran, rekayata, produksi, dan suatu pemeliharaan yang membuat suatu produk dan jasa tersebut sehingga konsumen menggunakan sesuai harapan atau keinginan konsumen (Andy Asmararaja \& Bagus Raka Suardana, 2018).

\section{METODE PENELITIAN}

Metode yang digunakan metode kuantitatif, responden dalam penelitian ini nasabah BRI Syariah KCP Ungaran yang beralamat di Jl Diponegoro No.247C, Sembungan, Ungaran Kec. Ungaran Barat, Kota Semarang, Jawa Tengah. Pengambilan sampe menggunakan simple random sampling. Teknik pengumpulan data dalam penelitian ini menggunakan teknik kuesioner. Menurut (Bawono, 2006) yakni pengambilan data yang diperoleh secara langsung yang dilakukan peneliti dari lapangan. Sumber data tersebut dapat diperoleh melalui cara dengan menggunakan angket (Questionare) yang artinya menggunakan daftar pertanyaan yang diberikan kepada objek dan selanjutnya akan dijawab pertanyaanya. Data diuji dengan uji instrumen (uji validasi, dan reabilitas), uji Asumsi Klasik (Uji Multikolonieritas, Heterokedasitas, Nomalitas, Ui Hipotesis (Uji T, F, dan R), serta Uji Path.

\section{HASIL DAN PEMBAHASAN}

Data yang digunakan merupakan data primer sehingga dalam menetapkan ketetapan model perlu dilakukan berbagai pengujian yaitu dari uji Validasi dan Uji Reabilitas dan Uji Asumsi Klasik yaitu Uji Multikolonieritas, Heterokedasitas, Nomalitas secara rinci dijelaskan sebagai berikut :

\section{Uji Reabilitas}

Uji Reabilitas Menurut (Bawono, 2006) memiliki tujuan menguji data yang sudah kita kumpulkan melalui kuesioner yang merupakan indikator dari variabel yang telah dijawab oleh para responden. Pengujian dilakukan dengan rumus Cronbach Alpha dimana suatu konstruk atau variabel yang realibel nilai Cronbach Alpha $>0,60$. Sehingga data tersebut bisa dikatakan reliabel untuk pengukuran dan meneliti selanjutnya .

Dari hasil penelitian dapat disimpulkan bahwa pengujian reabilitas dalam penelitian tersebut diperoleh dari nilai cronchback alpha > 0,060, maka variabel Corporate Social Responsilibity, Shariah Governanve, Kualitas Pelayanan, Keputusan Menabung dan Brand Image adalah reliable (handal).

\section{Uji Validasi}

Tujuannya mengukur sah/valid tidaknya kuisioner dalam melakukan penelitain. Kuisioner yang valid jika pada kuesioner pertanyaannya mampu secara tepat memberikan jawaban yang pas dari pertanyaan kuesioner.Dari hasil pengujian validasi diatas maka dapat disimpulkan bahwa pertanyaan yang digunakan peneliti dalam melakukan penelitian dengan menggunakan kuesioner adalah valid, karena semua item dalam pertanyaan disetiap variabel berbintang dua dan menunjukan pada level siginifikan 5\% sehingga tidak ada pertanyaan yang dihapus dan semua item pertanyaan tersebut digunakan seluruhnya dalam pengujian. 


\section{Uji Multikolonieritas}

Dari pengujian multikolonieritas terdapat nilai Tolerance tidak ada nilai variabel independen yang bernilai Tolenrance $<0,10$ yang dapat disimpulkan tidak ada korelasi diantara variabel independen tersebut. Selanjutnya dalam penelitian ini menunjukan hasil nilai VIF (VarianceInflationFactor) memiliki nilai > 10, sehingga dapat disimpulkan bahwa hasil penelitian tersebut tidak ada multikolonieritas antar variabel independen tersebut.

\section{Uji Heterokedasitas}

Mengetahui terjadi gejala heterokedasitas dapat menggunakan beberapa metode, seperti metode metode park. Dalam pengujian ini setiap variabel harus memiliki nilai signifikan lebih dari alfa (0.05) maka tidak menganduk heterokedaitas, jika nilai signifikan kurang dari $(0,05)$ maka terdapat gejala heterokedasitas.

Dari hasil penelitian dapat disimpulam bahwa penelitian tersebut diketahui nilai signifikan dalam setiap variabel lebih dari 0,05 (5\%), maka penelitian tersebut di ketahui bahwa tidak terjadi gejala heterokedasitas.

\section{Uji Normalitas}

Kegunaanya menguji model regresi, apakah data variabel yang diteliti bersifat dependen dan independen yang digunakan memiliki distribusi normal atau tidak. Dari penelitian dapat dismpulkan bahwa penelitian tersebut memiliki nilai signifikan 0,200 dan lebih besar dari 0,05 , maka hasil dari penelitian tersebut setiap variabel sudah berdistribusi normal.

\section{Analisis Data}

Pengujian ini menggunakan uji statistik F, Uji Koefisien Determinan $\mathrm{R}^{2}$, dan Uji Statistik T.

\section{a. Uji Statistik $\mathbf{F}$}

Tujuannya menentukan apakah variabel independen $(\mathrm{X} 1,2,3, .$.$) secara sendiri-$ sendiri dalam mempengaruhi variabel dependen (Y) atau terikat dan variabel independen $(\mathrm{X} 1,2,3, .$.$) secara sendiri-sendiri dalam mempengaruhi variabel$ intervening $(\mathrm{Z})$.

1) Hasil Uji F Test 1 CSR terhadap Keputusan Menabung

Dari penelitian dapat disimpulkan pengujian $\mathrm{F}$ test dalam penelitian tersebut memiliki nilai $\mathrm{F}$ hitung sebesar 80,375 dengan nilai signifikan 0,000 dimana nilai tersebut $>0,05$. Hasil tersebut memiliki arti bahwa setiap variabel CSR pengaruh secara positif dan juga signifikan terhadap Keputusan Menabung.

2) Hasil Uji F Test 2 Shariah Governance terhadap Keputusan Menabung

Dari penelitian dapat maka dapat disimpulkan pengujian $\mathrm{F}$ test memiliki nilai F hitung sebesar 83,296 dengan nilai signifikan 0,000 dimana nilai tersebut > 0,05. Hasil tersebut memiliki arti bahwa setiap variabel Shariah Governance berdampak secara positif dan juga signifikan terhadap Keputusan Menabung.

3) Hasil Uji F Test 3 Kualitas Pelayanan terhadap Keputusan Menabung

Dari penelitian dapat dapat disimpulkan pengujian $\mathrm{F}$ test dalam penelitian 
tersebut memiliki nilai $\mathrm{F}$ hitung sebesar 127,950 dengan nilai signifikan 0,000 dimana nilai tersebut $>0,05$. Hasil tersebut memiliki arti bahwa setiap variabel kualitas pelayanan berdampak secara positif dan juga signifikan terhadap Keputusan Menabung.

4) Hasil Uji F Test 4 Brand Image terhadap Keputusan Menabung

Dari penelitian dapat dapat disimpulkan bahwa hasil pengujian $\mathrm{F}$ test dalam penelitian tersebut memiliki nilai $\mathrm{F}$ hitung sebesar 120,471 dengan nilai signifikan 0,000 dimana nilai tersebut $>0,05$. Hasil tersebut memiliki arti bahwa setiap variabel brand image berdampak secara positif dan juga signifikan terhadap Keputusan Menabung.

\section{5) Hasil Uji F Test 5 CSR terhadap Brand Image}

Dari penelitian dapat dapat disimpulkan pengujian $\mathrm{F}$ test dalam penelitian tersebut memiliki nilai $F$ hitung sebesar 154,657 dengan nilai signifikan 0,000 dimana nilai tersebut $>0,05$. Hasil tersebut memiliki arti bahwa setiap variabel $C S R$ berdampak secara positif dan juga signifikan terhadap brand image.

6) Hasil Uji F Test 6 Shariah Governance terhadap Brand Image

Dari penelitian dapat maka dapat disimpulkan pengujian $\mathrm{F}$ test dalam penelitian tersebut memiliki nilai $\mathrm{F}$ hitung sebesar 187,498 dengan nilai signifikan 0,000 dimana nilai tersebut $>0,05$. Hasil tersebut memiliki arti bahwa setiap variabel shariah governance berdampak secara positif dan juga signifikan terhadap brand image.

7) Hasil Uji F Test 7 Kualitas Pelayanan terhadap Brand Image

Dari penelitian dapat maka dapat disimpulkan pengujian $F$ test dalam penelitian tersebut memiliki nilai $F$ hitung sebesar 146,175 dengan nilai signifikan 0,000 dimana nilai tersebut $>0,05$. Hasil tersebut memiliki arti bahwa setiap variabel kualitas pelayanan berdampak secara positif dan juga signifikan terhadap brand image.

\section{b. Uji Statistik $\mathbf{R}^{\mathbf{2}}$}

Menurut (Bawono, 2006) Tujuannya menunjukkan bagaimana keterikatan antara variabel dependen dan variabel independen dan variabel intervening $(Z)$ dan variabel independen dan bagaimana kontribusi variabel independen mempengaruhi variabel dependen.

1) Hasil Uji Koefisien Determinan $R^{2}$ (test 1) CSR terhadap Keputusan Menabung

Diketahu bahwa dalam pengujian memiliki nilai (R) sebesar 0,451 . Dalam hal ini dapat disimpulkan bahwa adanya hubungan yang kuat antara variabel independen CSR dengan variabel dependen (Keputusan Menabung). Sedangkan dilihat dari nilai $\left(\mathrm{R}^{2}\right)=0,451(45,1 \%)$ yang artinya variabel independen berdampak terhadap variabel dependen sebesar $45,1 \%$ yang sisanya 54,9\% dipengaruhi oleh variabel lain di luar model. 
2) Hasil Uji Koefisien Determinan $R^{2}$ (Test 2) Shariah Governance terhadap Keputusan Menabung

Dapat diketahui bahwa dalam pengujian memiliki nilai (R) sebesar 0,459. Dalam hal ini dapat disimpulkan bahwa adanya hubungan yang kuat antara variabel independen Shariah Governance dengan variabel dependen (Keputusan Menabung). Sedangkan dilihat dari nilai $\left(\mathrm{R}^{2}\right)=0,459(45,9 \%)$ yang artinya variabel independen mempengaruhi variabel dependen sebesar $45,9 \%$ yang sisanya $54,1 \%$ dipengaruhi oleh variabel lain di luar model.

3) Hasil Uji Koefisien Determinan $\mathrm{R}^{2}$ (Test 3) Kualitas Pelayanan terhadap Keputusan Menabung

Dapat diketahui bahwa dalam pengujian tersebut memiliki nilai (R) sebesar 0,566 . Dalam hal ini dapat disimpulkan bahwa adanya hubungan yang kuat antara variabel independen Kualitas Pelayanan dengan variabel dependen (Keputusan Menabung ). Sedangkan dilihat dari nilai $\left(\mathrm{R}^{2}\right)=0,566(56,6 \%)$ yang artinya variabel independen mempengaruhi variabel dependen sebesar 56,6\% yang sisanya 43,4\% dipengaruhi oleh variabel lain di luar model.

4) Hasil Uji Koefisien Determinan $\mathrm{R}^{2}$ (Test 4) Brand Image terhadap Keputusan Menabung

Diketahui bahwa dalam pengujian tersebut memiliki nilai (R) sebesar 0,551 Dalam hal ini dapat disimpulkan bahwa adanya hubungan yang kuat antara variabel independen brand image dengan variabel dependen (Keputusan Menabung ). Sedangkan dilihat dari nilai $\left(\mathrm{R}^{2}\right)=0,551(55,1 \%)$ yang artinya variabel independen mempengaruhi variabel dependen sebesar $55,1 \%$ yang sisanya $44,9 \%$ dipengaruhi oleh variabel lain di luar model.

5) Hasil Uji Koefisien Determinan $\mathrm{R}^{2}$ (Test 5) CSR terhadap Brand Image

Diketahui bahwa dalam pengujian tersebut memiliki nilai (R) sebesar 0,612 Dalam hal ini dapat disimpulkan bahwa adanya hubungan yang kuat antara variabel independen CSR dengan variabel dependen brand image. Sedangkan dilihat dari nilai $\left(\mathrm{R}^{2}\right)=0,612(61,2 \%)$ yang artinya variabel independen mempengaruhi variabel dependen sebesar $61,2 \%$ yang sisanya $38,8 \%$ dipengaruhi oleh variabel lain di luar model.

6) Hasil Uji Koefisien Determinan $\mathrm{R}^{2}$ (Test 6) Shariah Governance terhadap Brand Image

Diketahui bahwa dalam pengujian tersebut memiliki nilai (R) sebesar 0,657 Dalam hal ini dapat disimpulkan bahwa adanya hubungan yang kuat antara variabel independen Shariah Governance dengan variabel dependen brand image. Sedangkan dilihat dari nilai $\left(\mathrm{R}^{2}\right)=0,657(65,7 \%)$ yang artinya variabel independen mempengaruhi variabel dependen sebesar $65,7 \%$ yang sisanya $34,3 \%$ dipengaruhi oleh variabel lain di luar model. 
7) Hasil Uji Koefisien Determinan $\mathrm{R}^{2}$ (Test 7) Kualitas Pelayanan terhadap Brand Image

Dapat diketahui bahwa dalam pengujian tersebut nilai (R) sebesar 0,599 Hal ini dapat disimpulkan bahwa adanya hubungan yang kuat antara variabel independen kualitas pelayanan dengan variabel dependen brand image. Sedangkan dilihat dari nilai $\left(\mathrm{R}^{2}\right)=0,599(59,9 \%)$ yang artinya variabel independen mempengaruhi variabel dependen sebesar $59,9 \%$ yang sisanya $40,1 \%$ dipengaruhi oleh variabel lain di luar model.

c. Uji Statistik T (uji secara individu)

Tujuannya menentukan variabel independen dipengaruhi variabel dependen secara individu. Hipotesis diterima jika nilai t hitung sebesar > t tabel 1,661 dengan nilai signifikan $5 \%$.

1) Hasil Uji Statistik Pengaruh Parsial (T test) 1 Corporate Social Responsibility terhadap Keputusan Menabung

CSR (X1) nilai t hitung sebesar 8,965 > t tabel 1,661 dan memiliki nilai signifikan sebesar 0,00 pada koefisien alpha 5\%. Karena nilai signifikan $<0,05$, maka dapat disimpulkan bahwa CSR (X1) berpengaruh positif signifikan terhadap Keputusan Menabung (Y).

2) Hasil Uji Statistik Pengaruh Parsial (T test) 2 Shariah Governance terhadap Keputusan Menabung

Shariah Governance (X2) nilai t hitung sebesar 9,127>t tabel 1,661 dan memiliki nilai signifikan sebesar 0,00 pada koefisien alpha 5\%. Karena nilai signifikan < 0,05, maka dapat disimpulkan bahwa Shariah Governance (X2) berpengaruh positif signifikan terhadap Keputusan Menabung (Y)

3) Hasil Uji Statistik Pengaruh Parsial (T test) 3 Uji Kualitas Pelayanan terhadap

Keputusan Menabung

Kualitas Pelayanan (X3) nilai t hitung sebesar 11,318> t tabel 1,661 dan memiliki nilai signifikan sebesar 0,00 pada koefisien alpha 5\%. Karena nilai signifikan < 0,05, maka dapat disimpulkan bahwa Kualitas Pelayanan (X3) berpengaruh positif signifikan terhadap Keputusan Menabung(Y).

4) Hasil Uji Statistik Pengaruh Parsial (T test) 4 Uji Brand Image terhadap Keputusan Menabung

Brand Image $(\mathrm{Z})$ nilai t hitung sebesar 10,976 > t tabel 1,661 dan memiliki nilai signifikan sebesar 0,00 pada coefisien alpha 5\%. Karena nilai signifikan < 0,05, maka dapat disimpulkan bahwa Brand Image (Z) berpengaruh positif signifikan terhadap Keputusan Menabung (Y).

5) Hasil Uji Statistik Pengaruh Parsial (T test) 5 CSR terhadap Brand Image

CSR (X1) nilai $\mathrm{t}$ hitung sebesar 12,436>t tabel 1,661 dan memiliki nilai signifikan sebesar 0,00 pada koefisien alpha 5\%. Karena nilai signifikan $<0,05$, maka dapat disimpulkan bahwa CSR (X1) berpengaruh positif signifikan terhadap Brand Image (Z). 
6) Hasil Uji Statistik Pengaruh Parsial (T test) 6 Shariah Governance terhadap Brand Image

Shariah Governance (X2) nilai t hitung sebesar 13,693 > t tabel 1,661 dan memiliki nilai signifikan sebesar 0,00 pada koefisien alpha 5\%. Karena nilai signifikan < 0,05, maka dapat disimpulkan bahwa Shariah Governance (X2) berpengaruh positif signifikan terhadap Brand Image (Z).

7) Hasil Uji Statistik Pengaruh Parsial (T test) 7 Uji Kualitas Pelayanan terhadap Brand Image

Kualitas Pelayanan (X3) nilai t hitung sebesar 12,090 > t tabel 1,661 dan memiliki nilai signifikan sebesar 0,00 pada koefisien alpha 5\%. Karena nilai signifikan < 0,05, maka dapat disimpulkan bahwa Kualitas Pelayanan (X3) berpengaruh positif signifikan terhadap Brand Image $(\mathrm{Z})$.

\section{d. Uji Analisis Jalur (Path Analysis)}

Digunakan agar mengetahui pengaruh dari variabel interveningnya apakah mempengaruhi atau tidak dan digunakanlah analisis jalur regresi guna menaksir hubungan kausalitas antar variabel yang telah ditetapkan sebelumnya (Ghozali, 2018:254).

1) Pengaruh CSR ke Keputusan Menabung yang di Mediasi oleh Brand Image.

Dari perhitungan diatas maka dapat diketahui bahwa $t_{\text {hitung }}=10,017$ dimana lebih besar dari $t_{\text {tabel }}$ yaitu 1,661 dengan tingkat signifikan 0,05, kesimpulannya bahwa koefisien mediasi 0,0579 signifikan yang berarti berpengaruh mediasi. Maka Brand Image mampu memediasi pengaruh CSR terhadap Keputusan Menabung.

2) Pengaruh Shariah Governance terhadap Keputusan Menabung yang di Mediasi oleh Brand Image.

Dari perhitungan diatas maka dapat diketahui bahwa $t_{\text {hitung }}=11,335$ dimana lebih besar dari $t_{\text {tabel }}$ yaitu 1,661 dengan tingkat signifikan 0,05, kesimpulannya bahwa koefisien mediasi 0,0535 signifikan yang berarti berpengaruh mediasi. Maka Brand Image mampu memediasi pengaruh Shariah Governance terhadap Keputusan Menabung.

3) Pengaruh Kualitas Pelayanan terhadap Keputusan Menabung yang di Mediasi oleh Brand Image.

Dari perhitungan diatas maka dapat diketahui bahwa $t_{\text {hitung }}=8,12$ dimana lebih besar dari tabel yaitu 1,661 dengan tingkat signifikan 0,05, kesimpulannya bahwa koefisien mediasi 0,0708 signifikan yang berarti berpengaruh mediasi. Maka Brand Image mampu memediasi pengaruh Kualitas Pelayanan terhadap Keputusan Menabung. 


\section{E. PEMBAHASAN HASIL PENELITIAN}

Hasil dari pengujian hipotesis :

\section{CSR berpengaruh positif dan signifikan terhadap Keputusan Menabung}

Penelitian oleh Djunaedi (2016) mengatakan bahwa CSR menjadi daya tarik nasabah yang sangat baik, karena dalam konsep ini menunjukan dalam memenangkan persaingan dalam menarik masyarakat untuk memutuskan menabung. Pemberian CSR yang maksimal dan memperhatikan keluhan serta saran nasabah dapat mencapai kepuasan nasabah. Penelitian oleh Yulianti (2018) yang mengambil populasi dari Nasabah Bank Syariah Jateng dan Jogja bahwa CSR mempunyai mempunyai pengaruh yang positif dan signifikan terhadap Keputusan Menabung. Hal ini berarti dapat disimpulkan bahwa nasabah dapat dipengaruh secara signifikan oleh CSR dengan meningkatkan CSR maka Keputusan Menabung masyarakat mengalami peningkatan.

2. Shariah Governance berpengaruh positif dan signifikan terhadap Keputusan

\section{Menabung}

Penelitian yang sesuai oleh Said Aryonindito dan Tetet Fitrijanti (2018) yang meneliti pada Bank Muamalat dan hasil dari penelitian tersebut adalah Shariah Compliance berpengaruh positif terhadap Marker Share sehingga dapat meningkatan keputusan menabung masyarakat.

\section{Kualitas Pelayanan berpengaruh positif dan signifikan terhadap Keputusan Menabung}

Hasil penelitian terdahulu yang mendukung dilakukan oleh Fajar Fahrudin dan Yulianti (2015) yang meneliti tentang kualitas pelayanan terhadap keputusan pembelian yang menggunakan populasi nasabah Bank Mandiri di Surabaya yang menghasilkan kualitas pelayanan berpengaruh positif dan signifikan terhadap keputusan menabung. Upaya dalam meningkatkan masyarakat untuk melakukan keputusan menabung yaitu dengan memperhatikan kualitas pelayanan yang diberikan kepada nasabah karena dengan meningkatkan kualitas pelayanan maka berpengaruh positif dan nyata terhadap keputusan menabung suatu nasabah.

\section{Brand Image berpengaruh positif dan signifikan terhadap Keputusan Menabung}

Hasil penelitian yang mendukung penelitian ini yaitu Djunaedi (2016) yang meneliti tentang citra bank terhadap keputusan menabung yang menggunakan sampel dari nasabah BNI Syariah Kota Kediri penelitian ini menghasilkan bahwa citra bank mempunyai pengaruh yang positif dansignifikan terhadap keputusan menabung. Hal ini dikarenakan bahwa citra bank menjadi hal penting dan menjadi prioritas dalam dunia bisnis, karena sebelum nasabah melakukan pembiayaan maka nasabah menilai bagaimana citra merek dalam bisnis tersebut. Jika citra merek baik maka konsumen tertarik pada bisnis tesebut, jika citra bisnis tersebut buruk maka secara tidak langsung akan berdampak pada konsumen tidak tertarik pada bisnis tersebut.

\section{CSR berpengaruh positif dan signifikan terhadap Brand Image}

Penelitian ini sejalan dengan Astiti dan Safitri (2016) dimaka penelitian ini menggunakan sampel masyarakat Kota Denpasar yang menjadi nasabah. Hal ini 
dikarenakan citra baik atau buruk suatu perusahaan dikarenakan bagaimana perusahaan itu bertanggungjawab terhadap semua stakeholder, termasuk dalam pelanggan, pegawai, komunitas, kompetitor bahkan supplier yang dilakukan terus menerus yang telah mempercayai bank tersebut dengan melakukan kerjasama dengan bank tersebut.

\section{Shariah Governance berpengaruh positif dan signifikan terhadap Brand Image}

Penelitian ini sejalan dengan penelitian yang dilakukan oleh Kurnia (2017) yang meneliti tentang Good Corporate Governance terhadap Nilai Perusahaan yang hasilnya bahwa Good Corporate Governance mempunyai pengaruh positif dan signifikan terhadap nilai perusahaan. Hal ini dikarenakan apabila suatu prinsip kepatuhan syariah disuatu bank dilaksanakan dalam kegiatan pembiayaan di bank tersebut maka terciptanya suatu kepercayaan, dimana nasabah merasa aman dalam melakukan transaksi di perbankan tersebut sehingga citra baik perbanakan tersebut menjadi baik di benak nasabah.

\section{Kualitas Pelayanan berpengaruh positif dan signifikan terhadap Brand Image}

Penelitian yang mendukung dilakukan oleh Nurjanah dan Mulazid (2018) dimana meneliti bahwa kualitas pelayanan mempunyai pengaruh yang positif dan signifikan terhadap citra perusahaan. Hal ini dikarenakan bahwa jika perusahaan itu memberikan pelayanan yang baik maka citra perusahaan itu juga baik dimata masyarakat, sebaliknya jika kualitas pelayanan dalam perusahaan itu buruk maka citra perusahaan itu buruk.

8. CSR berpengaruh positif dan signifikan terhadap Keputusan Menabung dengan Brand Image sebagai Variabel Intervening

Penelitian yang mendukan dilakukan oleh Yulianti (2017) yang melakukan penelitian yang menghasilkan bahwa CSR mempengaruhi secara positif dan signifikan terhadap keputusan menabung yang di mediasi oleh citra perusahaan. Hal ini dikarenakan bahwa pengaruh langsung variabel CSR terhadap keputusan menabung lebih besar dari pada pengaruh tidak langsung variabel CSR terhadap keputusan menabung.

9. Shariah Governance berpengaruh positif dan signifikan terhadap Keputusan Menabung dengan Brand Image sebagai Variabel Intervening

Penelitian ini sejalan dengan penelitian Ruwaidah (2018) yang meneliti bahwa shariah governance berpengaruh positif dan signifikan terhadap keputusan nasabah menggunakan produk di lembaga keuangan syariah. Hasil yang diperoleh tersebut menunjukan jika perbankan menggunakan prinsip-prinsip syariah dalam melakukan pembiayaannya maka citra bank tersebut menjadi baik dan nasabah merasa yakin jika melakukan pembiyaan di bank tersebut.

\section{Kualitas Pelayanan berpengaruh positif dan signifikan terhadap Keputusan}

\section{Menabung dengan Brand Image sebagai Variabel Intervening}

Hasil penelitian ini sejalan dengan penelitian yang dilakukan oleh Siti Munawaroh (2018) yang melakukan penelitian tentang pengaruh kualitas produk terhadap keputusan menabung dengan dimediasi oleh brand image yang menunjukan jika brand image mempunyai pengaruh positif untuk memediasi pengaruh kualitas produk terhadap keputusan menabung. Hal ini dikarenakan bahwa pengaruh langsung variabel kualitas pelayanan terhadap keputusan menabung lebih besar dari pada pengaruh tidak langsung 
variabel kualitas pelayanan terhadap keputusan menabung.

\section{F. KESIMPULAN}

Berdasarkan hasil penelitian yang telah dijelaskan di atas maka dapat disimpulkan bahwa variabel CSR, Shariah Governance, dan Kualitas pelayanan sama-sama berpengaruh positif dan signifikan terhadap keputusan menabung, dan variabel intervening juga memediasi yang positf dan signifikan.

\section{DAFTAR PUSTAKA}

Andy Asmararaja, I. kadek, \& Bagus Raka Suardana, I. (2018). Tingkat Kepercayaan, Kualitas Layanan, Brand Preference dan Minat Menabung. Jurnal Manajemen Bisnis, 15(1). http://journal.undiknas.ac.id/index.php/magister-manajemen/

Astiti, N. P. Y., \& Saitri, P. W. (2016). Pengaruh Corporate Social Responsibility Terhadap Kesejahteraan Masyarakat dan Citra Perusahaan. Jurnal Bisnis Dan Kewirausahaan, 12(2), 94-104.

Bawono, A. (2006). Multivariate Analysis dengan SPSS.

Caesario, R. D., Niaga, A., Malang, P. N., \& Nasabah, K. (2018). Pengaruh Corporate Social Responsibility ( Csr ) Dan Kepuasan Nasabah Terhadap Citra Perusahaan Di Bri. J A B Jurnal Aplikasi Bisnis, 4(1).

Djunaedi. (2016). Pengaruh Corporate Social Responsibility ( CSR ), dan Kualitas Produk Terhadap, Citra Bank dan Keputusan Menabung di BNI Syariah Kota Kediri. 3(2).

Endraswati, H. (2017). Struktur Islamic Corporate Governance.

Fahham, A. M., Suryani, A. S., Wahyuni, D., Astri, H., Hakim, L. N., Mulyadi, M., Teja, M., Prihatin, R. B., \& Prayitno, U. S. (2015). Corporate Social Responsibility: Konsep, Strategi, dan Perusahaan.

Fajar Fahrudin, M., \& Yulianti, E. (2015). Pengaruh promosi, lokasi, dan kualitas layanan terhadap keputusan pembelian nasabah Bank Mandiri Surabaya. Journal of Business \& Banking, 5(1), 149. https://doi.org/10.14414/jbb.v5i1.478

Haris, H., \& T, N. S. I. (2012). Pengaruh Kualitas Pelayanan dan Periklanan terhadap Keputusan Nasabah dalam Menabung pada Bank Syariah (Studi Kasus pada BTN Syariah Surakarta). Muqtasid: Jurnal Ekonomi Dan Perbankan Syariah, 3(1), 1. https://doi.org/10.18326/muqtasid.v3i1.1-24

Inayati, L. S., \& Wahyuni, D. U. (2017). Pengaruh Kesadaran Merek, Persepsi Kualitas, Dan Promosi Periklanan Terhadap Keputusan Pembelian Handphone Samsung. Favian Firwan Firdaus, 6(4), 1-20.

Kurnia, D. (2017). Pengaruh Good Corporate Governance Dan Ukuran Perusahaan Terhadap Nilai Perusahaan Pada Perusahaan Food And Beverage Yang Listing Di Bursa Efek Indonesia БезопасностьNo Title. JOM FISIP, 4, 9-15.

Maski, G. (2010). Analisis Keputusan Nasabah Menabung: Pendekatan Komponen Dan Model

e1-Jizya: Jurnal Ekonomi Islam, Vo1. 9, No. 1, Januari-Juni 2021

68 I http://ejournal.iainpurwokerto.ac.id/index.php/eljizya 
Logistik Studi Pada Bank Syariah Di Malang. Journal of Indonesian Applied Economics, 4(1), 1-2010. https://doi.org/10.21776/ub.jiae.2010.004.01.4

Munawaroh, S. (2018). Pengaruh Promosi, Kualitas Produk Dan Kualitas Layanan Terhadap Keputusan Menabung Dengan Brand Image Sebagai Variabel Intervening. Skripsi.

Nofriyanti, A. R. (2017). Pengaruh Brand Trust, Brand Image, Perceived Quality, Brand Loyalty Terhadap Brand Equity Pengguna Telkomsel. Jurnal Ekonomi BisnisEkonomi Bisnis, 22(2), 130-142.

Nurjanah, R., \& Mulazid, A. S. (2018). Pengaruh Kualitas Pelayanan dan Corporate Social Responsibility Terhadap Citra Perusahaan. Muqtasid: Jurnal Ekonomi Dan Perbankan Syariah, 9(1), 40. https://doi.org/10.18326/muqtasid.v9i1.40-53

OJK. (2020). Snapshot Perbankan Syariah Indonesia Maret 2020. Otoritas Jasa Keuangan. https://www.ojk.go.id/id/kanal/syariah/berita-dan-

kegiatan/publikasi/Documents/Pages/Snapshot-Perbankan-Syariah-Indonesia-Maret2020

Ramadani, O. V., Kadir, A. R., \& Sanusi, A. (2018). Analisis Pengaruh Shariah Compliance dan Assurance terhadap Kepuasan Nasabah BMT Barokatul Umah di Kabupaten Merauke. Economica: Jurnal Ekonomi Islam, 9(2), 349. https://doi.org/10.21580/economica.2018.9.2.2662

Ruwaidah, S. H. (2018). Pengaruh literasi keuangan syariah dan shariah governance terhadap keputusan mahasiswa dalam menggunakan jasa perbankan syariah: studi kasus pada .... Muhasabatuna: Jurnal Akuntansi Dan Keuangan Islam, 1, 79-106. http://eprints.walisongo.ac.id/8966/

Said, A. (2016). Pengaruh Brand Image, Word Of Mouth, Dan Iklan Terhadap Minat Menabung Di BMT Se-Kabupaten Demak. Equilibrium: Jurnal Ekonomi Syariah, 4(2), 318-333.

Said Aryonindito, T. F. (2018). Pengaruh Sharia Compliance, Transparansi, Dan Akuntabilitas Terhadap Market Share Bank Umum Syariah. Akuntabilitas Dalam Perspektif Teori Agensi, 02(02), 357-370.

Yulianti, Hayu Yolanda Utami, \& Natassia, R. (2017). Pengaruh Corporate Social Responsibility, Kualitas Produk, Dan Kualitas Pelayanan Terhadap Keputusan Menabung Dengan Brand Image Sebagai Variabel Intervening Pada Bank Nagari Cab. Utama. 